\title{
Perlakuan Celup Puting setelah Pemerahan terhadap Keberadaan Bakteri Patogen, Staphylococcus aureus, Streptococcus agalactiae, dan E. coli pada Sapi Perah Penderita Mastitis Subklinis di Peternakan KUNAK Bogor
}

\author{
Teat Dipping Treatment after Milking Process to The Presence of Pathogenic Bacteria, \\ Staphylococcus aureus, Streptococcus agalactiae, and E. coli in Dairy Cattle with \\ positive Subclinical Mastitis at Kunak Bogor
}

\section{Herwin Pisestyani ${ }^{1}$, Etih Sudarnika ${ }^{1}$, Rachmi Ramadhanita ${ }^{2}$, Abdul Zahid Ilyas ${ }^{1}$, Ardilasunu Wicaksono $^{1}$, Chaerul Basri', Arifin Budiman Nugraha ${ }^{3}$, Mirnawati B. Sudarwanto ${ }^{1}$}

\author{
${ }^{1}$ Divisi Kesehatan Masyarakat Veteriner, Departemen Ilmu Penyakit Hewan dan \\ Kesehatan Masyarakat Veteriner, Fakultas Kedokteran Hewan, Institut Pertanian Bogor \\ ${ }^{2}$ Fakultas Kedokteran Hewan, Institut Pertanian Bogor \\ ${ }^{3}$ Divisi Parasitologi Entomologi Kedokteran, Departemen Ilmu Penyakit Hewan dan \\ Kesehatan Masyarakat Veteriner, Fakultas Kedokteran Hewan, Institut Pertanian Bogor \\ J1. Agatis Kampus IPB Darmaga Bogor 16680 \\ Email: herwinpi@gmail.com
}

\begin{abstract}
Mastitis is udder inflammation that can be caused by the entry of pathogenic bacteria through the teat. One of the treatments that can prevent bacteria infection is teat dipping. This research was aimed to identify the effect of teat dipping after milking to the presence of pathogenic bacteria that cause subclinical mastitis (Staphylococcus aureus, Streptococcus agalactiae, and Escherichia coli) and the presence of pathogenic bacteria that cause subclinical mastitis by quarter of udder. Milk samples were taken from normal lactation period of dairy cows, clinically healthy, and positive subclinical mastitis status when the intervention was applied. Sixty seven samples of quarters from 18 dairy cows were identified to the presence of pathogenic bacteria that cause subclinical mastitis before teat dipping and at 1st, 2nd, and 3rd months after teat dipping. Identification of the presence of pathogenic bacteria was done by culturing samples on selective agar media. The presence of common pathogenic bacteria, Staphylococcus aureus, and Escherichia coli decreased significantly after teat dipping, while Streptococcus agalactiae and other pathogenic bacteria did not decrease significantly. The presence of pathogenic bacteria based on the quarter of udder did not show the significance difference. Application of teat dipping after milking was able to decrease the presence of pathogenic bacteria that cause subclinical mastitis.
\end{abstract}

Keywords: pathogenic bacteria, subclinical mastitis, teat dipping

\begin{abstract}
Abstrak
Mastitis merupakan peradangan ambing yang dapat disebabkan oleh masuknya bakteri melalui lubang puting. Salah satu kegiatan yang dapat mencegah infeksi bakteri ke dalam jaringan internal ambing adalah celup puting setelah pemerahan. Penelitian ini bertujuan mengidentifikasi pengaruh celup puting setelah pemerahan terhadap keberadaan bakteri patogen, Staphylococcus aureus, Streptococcus agalactiae, dan Escherichia coli pada sapi perah positif mastitis subklinis serta menganalisa keberadaan bakteri tersebut berdasarkan posisi puting. Sampel susu yang digunakan berasal dari sapi perah dalam masa laktasi normal, sehat secara klinis, dan positif menderita mastitis subklinis sebelum diberi perlakuan celup puting. Sejumlah 67 sampel kuartir dari 18 ekor sapi perah diidentifikasi terhadap keberadaan bakteri patogen, Staphylococcus aureus, Streptococcus agalactiae, dan E. coli
\end{abstract}


sebelum perlakuan celup puting dan pada bulan ke-1, ke-2, dan ke-3 setelah perlakuan celup puting. Keberadaan bakteri patogen diidentifikasi dengan cara melihat zona hemolisa pada media agar darah, sedangkan bakteri lainnya dibiakkan pada media agar selektif sesuai dengan jenis bakteri yang akan diidentifikasi. Hasil penelitian ini menunjukkan bahwa keberadaan bakteri patogen, Staphylococcus aureus, dan Escherichia coli mengalami penurunan yang nyata setelah diberi perlakuan celup puting, sedangkan Streptococcus agalactiae tidak mengalami penurunan yang nyata. Posisi puting tidak berpengaruh terhadap keberadaan bakteri patogen, Staphylococcus aureus, Streptococcus agalactiae, dan E. coli. Simpulan dari penelitian ini adalah aplikasi celup puting setelah pemerahan dapat mengurangi keberadaan bakteri patogen pada sapi perah penderita mastitis subklinis.

Kata kunci: bakteri patogen, celup puting, mastitis subklinis

\section{Pendahuluan}

Susu merupakan bahan makanan yang mengandung nutrisi penting sehingga sangat baik untuk dikonsumsi masyarakat, namun produksi susu di Indonesia masih kurang maksimal sehingga belum mampu memenuhi kebutuhan konsumsi susu dalam negeri. Indonesia mengimpor susu sebanyak 900.000 ton atau $70 \%$ dari kebutuhan nasional pada tahun 2012 (DITJENNAK KESWAN, 2013). Kawasan Usaha Peternakan (KUNAK) Bogor memiliki target produksi susu sebanyak 20.000 liter/hari pada tahun 2013, namun sampai akhir tahun 2013 kawasan ini hanya mampu mencapai $40 \%$ dari target yakni 8.000 liter/hari (GKSI, 2013). Banyak faktor yang menyebabkan produksi susu kurang maksimal, salah satunya penyakit yang sering dialami oleh ternak perah yaitu radang ambing atau yang dikenal sebagai mastitis. Saat ini mastitis masih menjadi masalah utama yang terjadi di peternakan rakyat (Nurhayati\& Martindah, 2014).

Mastitis merupakan peradangan pada jaringan internal ambing (Subronto, 2003). Secara ekonomi, mastitis sangat merugikan peternak karena dapat menurunkan produksi susu. Prevalensi mastitis pada sapi perah di Indonesia sangat tinggi (85\%) dan sebagian besar merupakan infeksi yang bersifat subklinis (Poeloengan, 2010). Mastitis subklinis tidak menampakkan gejala klinis sehingga sering tidak disadari oleh peternak. Penyebab terjadinya mastitis diantaranya yaitu kuman patogen (infeksius) seperti bakteri dan virus; kerusakan fisik ambing (udder and teat injury); serta paparan bahan kimia iritan yang mampu merusak jaringan interna ambing, namun sebagian besar kejadian mastitis disebabkan oleh bakteri. Bakteri yang dapat menyebabkan mastitis diantaranya yaitu Streptococcus agalactiae, Streptococcus dysgalactiae, Streptococcus uberis, Staphylococcus aureus, Staphylococcus epidermidis, Escherichia coli, Escherichia freundii, Aerobacter aerogenes, dan Klebsiella pneumoniae (Poeloengan, 2010). Menurut penelitian-penelitian sebelumnya, bakteri penyebab mastitis yang paling sering ditemukan yaitu Staphylococcus aureus, Streptococcus agalactiae, Staphylococcus epidermidis, dan Escherichia coli, sehingga efektivitas upaya pengendalian mastitis terhadap keberadaan bakteri-bakteri tersebut penting untuk dipelajari. Keberadaan mikroba patogen penyebab mastitis dapat berbeda untuk setiap puting pada seekor sapi terkait dengan kontak puting terhadap alas kandang dan urutan puting yang diperah.

Proses penularan agen penyebab mastitis dapat terjadi pada saat pemerahan susu secara manual melalui tangan pemerah, air yang dipakai untuk membersihkan ambing, kain lap atau peralatan lain yang dipakai pada saat pemerahan (Supar dan Ariyanti, 2008). Mikroba yang menyebabkan terjadinya mastitis dapat berasal dari luar ambing 
yang masuk melalui puting saat proses pemerahan ataupun setelah proses pemerahan saat kondisi lubang puting masih terbuka. Salah satu kegiatan setelah pemerahan yang dapat menurunkan kejadian mastitis adalah celup puting (Putri dkk., 2015). Tindakan celup puting dengan menggunakan antiseptik bertujuan untuk mencegah masuknya bakteri ke dalam ambing melalui lubang puting. Larutan yang umum digunakan untuk celup puting yaitu Iodine, Chlorhexidine, Chlorin 4\%, dan alkohol 70\% (Siregar, 2010).

Efektivitas aplikasi celup puting untuk mengurangi keberadaan bakteri patogen penyebab mastitis subklinis belum banyak diteliti sehingga perlu dilakukan penelitian untuk mengidentifikasi pengaruh aplikasi celup puting terhadap keberadaan bakteri patogen penyebab mastitis subklinis baik secara keseluruhan maupun berdasarkan posisi puting. Penelitian ini bertujuan mengkaji pengaruh aplikasi celup puting setelah pemerahan terhadap keberadaan bakteri patogen, Staphylococcus aureus, Streptococcus agalactiae, dan Escherichia coli, serta menganalisa keberadaan bakteri tersebut berdasarkan posisi puting perah di Kawasan Usaha Peternakan (KUNAK) Kecamatan Cibungbulang Kabupaten Bogor.

\section{Materi dan Metode}

Pengambilan sampel dilakukan di Kawasan Usaha Ternak (KUNAK) Kecamatan Cibungbulang Kabupaten Bogor. Penelitian ini diawali dengan memilih peternak yang mempunyai sapi dalam masa laktasi normal, sehat secara klinis, dan positif mastitis subklinis sebelum diberi perlakuan celup puting. Masa laktasi normal pada sapi perah adalah bulan ke-3 sampai bulan ke-5 postpartus saat sapi perah sedang memproduksi susu. Pemilihan sapi perah yang berada dalam masa laktasi normal dilakukan untuk mencegah terjadinya hasil uji positif palsu terhadap pengujian mastitis subklinis yang dapat disebabkan oleh kondisi fisiologis normal ternak, yaitu pada masa awal laktasi dan akhir laktasi. Pengujian mastitis subklinis dilakukan menggunakan pereaksi IPB-1. Pereaksi IPB-1 akan bereaksi dengan DNA dari inti sel somatis pada susu yang berasal dari sapi yang menderita mastitis subklinis, sehingga tebentuk massa kental seperti gelatin (Sudarwanto, 1998). Berdasarkan hasil pemilihan tersebut, diperoleh 18 ekor sapi dengan jumlah puting sebanyak 67 kuartir yang digunakan dalam penelitian.

Peternak yang memiliki sapi yang dijadikan sampel penelitian, diberi penyuluhan dan diberi bantuan alat celup puting (teat dipper) serta larutan antiseptik. Penyuluhan yang diberikan meliputi pengetahuan tentang mastitis subklinis dan kualitas susu serta proses dan waktu perlakuan celup puting. Pencelupan puting dilakukan setelah pemerahan oleh peternak di kandang masing-masing dengan cara mencelupkan puting ke dalam teat dipper yang berisi larutan antiseptik selama 5-10 detik untuk setiap puting. Perlakuan celup puting diberikan selama 3 bulan pengamatan, yaitu pada saat sapi perlakuan masih berada dalam rentang masa laktasi normal, sehingga mencegah terjadinya kesalahan pembacaan hasil uji mastitis subklinis. Pengambilan dan pengujian sampel dilakukan sebelum perlakuan celup puting (bulan ke-0) dan pada bulan ke-1, ke-2, dan ke-3 setelah perlakuan celup puting.

Proses pengambilan sampel diawali dengan membersihkan ambing sapi yang akan diperah dengan air bersih lalu dilap, susu pancaran pertama dibuang dan pancaran selanjutnya diambil sebanyak $10 \mathrm{ml}$ dari setiap kuartir dan ditampung dalam botol sampel 
yang telah diberi kode, kemudian botol ditutup rapat dan disimpan ke dalam cool box dengan suhu $\pm 4{ }^{\circ} \mathrm{C}$.

Alat yang digunakan pada tahap pengambilan sampel yaitu botol sampel yang telah diberi kode, lap bersih, ice pack, dan cool box. Alat yang digunakan pada tahap pengujian di laboratorium yaitu pembakar bunsen, vortex, ose, inkubator serta cawan petri yang telah diberi kode sampel dan diisi media. Selain itu, digunakan pula paddle untuk uji IPB Mastitis dan alat untuk celup puting (teat dipper). Bahan yang digunakan adalah pereaksi IPB-1, alkohol 70\%, povidone iodine $1 \%$ dan gliserin $10 \%$, sampel susu, Blood Agar Base (Oxoid® CM0055), Mannitol Salt Agar (Oxoid® CM0085), dan Coliform Selective Medium (Oxoid ${ }^{\circledR}$ CM1046).

\section{Prosedur Identifikasi Keberadaan Bakteri}

Sampel susu kuartir digores sebanyak 1 ose pada masing-masing media agar. Media Blood Agar untuk mengidentifikasi keberadaan bakteri patogen, Mannitol Salt Agar untuk mengidentifikasi keberadaan S. aureus, serta Coliform Selective Medium untuk mengidentifikasi keberadaan E. coli. Masing-masing biakkan diinkubasikan selama 20-24 jam pada suhu 35-37 ${ }^{\circ} \mathrm{C}$. Keberadaan bakteri patogen yang tumbuh pada Blood Agar diidentifikasi dengan mengamati terbentuknya zona hemolisa (bening) di sekeliling koloni bakteri. Koloni yang diduga S. agalactiae yaitu membentuk hemolisis tidak sempurna (hemolisis alpha) dilanjutkan dengan uji CAMP (Christie, Atkins, Munch-Peterson). Uji CAMP dilakukan pada Blood Agar dengan bakteri S. aureus sebagai penanda kemudian diinkubasi selama 24-48 jam pada suhu $37{ }^{\circ} \mathrm{C}$. Setelah inkubasi, koloni S. agalactiae akan memperlihatkan hasil uji positif yang ditunjukkan dengan terjadinya zona hemolisis berbentuk mata anak panah di sebelah goresan S. aureus (Gambar 1a). Media Mannitol Salt Agar merupakan media selektif bagi pertumbuhan $S$. aureus yang dapat membedakan dengan spesies Staphylococcus lainnya. S. aureus ditunjukkan dengan tumbuhnya koloni berwarna kuning dan media agar berubah dari warna merah menjadi kuning (Gambar 1b) sedangkan bakteri Staphlococcus sp lainnya membentuk koloni berwarna merah muda. Media Coliform Selective Medium digunakan untuk membedakan E. coli dengan jenis bakteri koliform yang lain. E. coli akan membentuk koloni berwarna ungu (Gambar 1c) sedangkan bakteri koliform yang lain akan membentuk koloni berwarna merah muda, biru ataupun tidak berwarna.



a

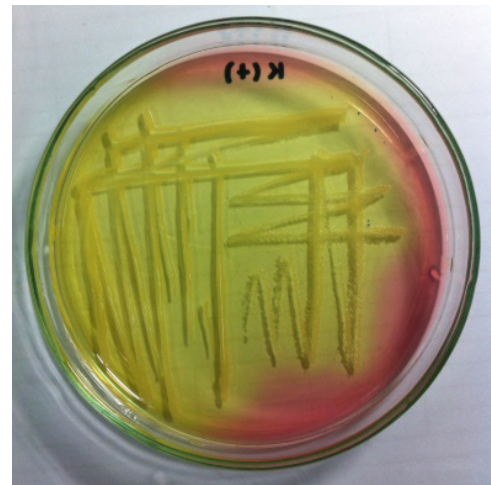

b

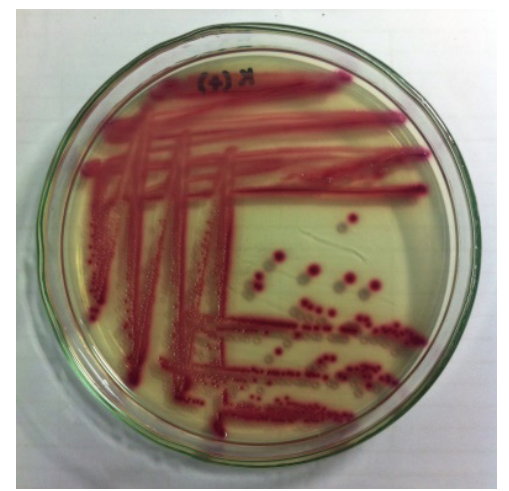

$\mathrm{C}$

Gambar 1. (a) hasil positif uji CAMP (b) kontrol positif S. aureus pada media Mannitol Salt Agar (c) kontrol positif E. coli pada media Coliform Selective Medium 
Keberadaan bakteri dihitung dengan menjumlahkan bakteri yang dapat tumbuh pada masing-masing media (positif), sedangkan yang tidak tumbuh maka dinyatakan negatif.

\section{Analisis Data}

Data dianalisis dengan uji khi-kuadrat dengan tingkat kepercayaan 95\% untuk mengetahui perbedaan persentase puting yang terinfeksi bakteri patogen pada setiap bulan pengamatan, dan perbedaan persentase puting yang terinfeksi bakteri pathogen menurut posisi puting.

\section{Hasil dan Pembahasan}

\section{Keberadaan Bakteri Patogen Penyebab Mastitis} Subklinis setelah Aplikasi Celup Puting

Keberadaan bakteri patogen penyebab mastitis subklinis dapat bersifat kompleks, artinya beberapa jenis bakteri patogen dapat berada pada puting yang sama. Aplikasi celup puting menggunakan larutan povidone iodine $1 \%$ dan gliserin $10 \%$ secara umum dapat menurunkan keberadaan bakteri patogen penyebab mastitis subklinis, namun penurunan yang terjadi tidak merata pada semua jenis bakteri.
Berdasarkan Tabel 1, keberadaan bakteri patogen, $S$. aureus, dan E. coli mengalami penurunan yang nyata setelah diberi perlakuan celup puting, sedangkan $S$. agalactiae tidak mengalami penurunan yang nyata. Keduanya hanya mengalami penurunan pada bulan ke-2 setelah diberi perlakuan celup puting.

Povidone iodine mempunyai spektrum luas dan merupakan iodine kompleks yang berfungsi sebagai antiseptik yang dapat menghambat pertumbuhan mikroba yang ada di dalam atau di atas jaringan hidup (Brooks dkk., 2008). Aplikasi celup puting menggunakan povidone iodine dapat menghambat pertumbuhan bakteri dengan cara melapisi lubang puting, sehingga mikroba yang masuk ke dalam lubang puting terlapisi oleh zat iodium yang dapat merusak dinding sel bakteri bagian luar dan membran sel, kemudian menembus sitoplasma sampai ke inti sel dengan merusak metabolisme sel mikrobaa sehingga perkembangbiakkan bakteri akan terhambat sampai akhirnya bakteri mati (Mahardhika dkk., 2012). Penggunaan povidone iodine adalah solusi sederhana dan ekonomis untuk mengurangi infeksi. Penurunan yang nyata pada keberadaan bakteri patogen, S. aureus, dan E. coli menunjukkan bahwa povidone iodine efektif untuk menurunkan keberadaan bakteri-bakteri tersebut.

Tabel 1. Persentase puting yang terinfeksi bakteri patogen penyebab mastitis subklinis karena perlakuan celup puting pada setiap bulan pengamatan

\begin{tabular}{|c|c|c|c|c|c|c|}
\hline \multirow{2}{*}{ Jenis bakteri } & \multicolumn{4}{|c|}{$\begin{array}{l}\text { Persentase puting yang terinfeksi }(\%) \\
\text { (Selang kepercayaan } 95 \%)\end{array}$} & \multirow[b]{2}{*}{$\chi^{2}$} & \multirow[b]{2}{*}{$\mathrm{P}$} \\
\hline & $\begin{array}{c}\text { Bulan ke-0 } \\
(\mathrm{n}=67)\end{array}$ & $\begin{array}{c}\text { Bulan ke-1 } \\
(\mathrm{n}=67)\end{array}$ & $\begin{array}{c}\text { Bulan ke-2 } \\
(\mathrm{n}=67)\end{array}$ & $\begin{array}{c}\text { Bulan ke-3 } \\
(\mathrm{n}=65)\end{array}$ & & \\
\hline Bakteri patogen & $\begin{array}{l}97 \\
(90-99)\end{array}$ & $\begin{array}{l}87 \\
(76-93)\end{array}$ & $\begin{array}{l}63 \\
(51-73)\end{array}$ & $\begin{array}{l}34 \\
(24-46)\end{array}$ & 74.625 & $<0.0001^{*}$ \\
\hline S. agalactiae & $\begin{array}{l}16 \\
(9-27)\end{array}$ & $\begin{array}{l}13 \\
(7-24)\end{array}$ & $\begin{array}{l}9 \\
(4-18)\end{array}$ & $\begin{array}{l}9 \\
(4-18)\end{array}$ & 2.423 & 0.4893 \\
\hline S. aureus & $\begin{array}{l}75 \\
(63-84)\end{array}$ & $\begin{array}{l}55 \\
(43-67)\end{array}$ & $\begin{array}{l}39 \\
(28-51)\end{array}$ & $\begin{array}{l}23 \\
(15-35)\end{array}$ & 38.868 & $<0.0001^{*}$ \\
\hline E. coli & $\begin{array}{l}52 \\
(40-64)\end{array}$ & $\begin{array}{l}30 \\
(20-42)\end{array}$ & $\begin{array}{l}13 \\
(7-24)\end{array}$ & $\begin{array}{l}8 \\
(3-17)\end{array}$ & 41.376 & $<0.0001 *$ \\
\hline
\end{tabular}

* Menunjukkan perbedaan yang nyata pada $\mathrm{P}<0.05$ 
Penurunan yang terjadi tidak merata pada semua jenis bakteri, meskipun povidone iodine merupakan antiseptik yang memiliki spektrum luas. Hal tersebut dapat dipengaruhi oleh beberapa faktor, salah satunya adalah faktor patogenitas dari bakteri yang dapat mempengaruhi efektivitas povidone iodine (Connors, 1992). Selain itu, sanitasi kandang yang buruk dapat menurunkan efektivitas perlakuan celup puting dalam menurunkan keberadaan bakteri. Proses sanitasi kandang di KUNAK sangat bergantung pada ketersediaan air. Kondisi wilayah kandang mengalami kekeringan pada bulan ke-3 karena memasuki musim kemarau sehingga sanitasi kandang tidak terjaga dengan baik. Keberadaan S. agalactiae tidak mengalami penurunan pada bulan tersebut, hal ini dapat terjadi karena $S$. agalactiae tahan pada kondisi lingkungan yang kering (Ryan and Ray, 2004). Selain itu, S. agalactiae memiliki kapsul polisakarida yang menjadi faktor patogenitas sehingga $S$. agalactiae dapat lebih tahan terhadap pemberian antiseptik, terlebih pada kondisi lingkungan yang mendukung keberadaan bakteri tersebut seperti kondisi sanitasi yang buruk pada bulan ke-3. Menurut Songer and Post (2005), pengendalian infeksi S. agalactiae pada kasus mastitis subklinis lebih efektif menggunakan injeksi antibiotik intramammari pada periode kering kandang. Keberadaan bakteri patogen selain yang diidentifikasi juga tidak mengalami penurunan pada bulan ke-3 diduga terkait dengan kondisi sanitasi kandang yang buruk.

E. coli merupakan bakteri yang keberadaannya sangat terkait dengan sanitasi yang buruk, namun E. coli tetap mengalami penurunan meskipun pada bulan ke-3 kondisi sanitasi kandang tidak terjaga. E. coli memiliki banyak serotipe dengan tingkat patogenitas yang berbeda-beda. E. coli yang terdapat pada kasus mastitis subklinis merupakan serotipe yang menyerupai E. coli dalam usus sehingga pengendaliannya cukup efektif dengan menggunakan antiseptik spektrum luas (White, 2006). Efektivitas povidone iodine terhadap keberadaan E. coli cukup tinggi sehingga dapat menurunkan keberadaan bakteri tersebut meskipun pada keadaan kondisi sanitasi kandang yang buruk.

\section{Keberadaan Bakteri Patogen Penyebab Mastitis Subklinis berdasarkan Posisi Puting}

Asosiasi keberadaan bakteri patogen terhadap posisi puting diteliti dengan menguji keberadaan bakteri pada sampel susu dari setiap kuartir pada pengamatan bulan ke-0 (sebelum perlakuan) sampai dengan bulan ke-3 setelah perlakuan, sehingga diperoleh besaran sampel untuk setiap posisi puting seperti tertera pada Tabel 2.

Tabel 2 Persentase puting yang terinfeksi bakteri patogen penyebab mastitis subklinis berdasarkan posisi puting pada perlakuan celup puting

\begin{tabular}{lcccc}
\hline Posisi puting & $\begin{array}{c}\text { Jumlah pen- } \\
\text { gamatan (n) }\end{array}$ & $\begin{array}{c}\text { Persentase puting yang terinfeksi (\%) } \\
\text { (Selang kepercayaan 95\%) }\end{array}$ & $\chi^{2}$ & P \\
\hline Kanan depan & 60 & $58(43-71)$ & 2.372 & 0.4988 \\
Kiri depan & 68 & $69(55-80)$ & & \\
Kanan belakang & 64 & $64(50-75)$ & \\
Kiri belakang & 68 & $55(41-68)$ & \\
\hline
\end{tabular}


Bakteri patogen penyebab mastitis subklinis yang masuk ke dalam ambing melalui lubang puting dapat berasal dari lingkungan kandang sehingga kontak tubuh sapi dengan alas kandang dapat mempengaruhi keberadaan bakteri tersebut. Posisi rumen sapi yang berada di bagian tubuh sebelah kiri menyebabkan sapi lebih nyaman berbaring ke sebelah kanan pada saat ruminansi agar tidak menekan rumen. Selain itu, posisi jantung yang berada di sebelah kiri juga menyebabkan sapi lebih nyaman berbaring ke sebelah kanan pada saat istirahat karena posisi berbaring ke sebelah kanan dapat menurunkan tekanan darah sehingga dapat meningkatkan kualitas istirahat (Muttaqin, 2009).

Kecenderungan sapi berbaring ke sebelah kanan menyebabkan puting sebelah kanan lebih sering berkontak dengan alas kandang termasuk pada saat kondisi alas kandang belum dibersihkan, sehingga dapat meningkatkan risiko penularan bakteri patogen penyebab mastitis subklinis yang berasal dari lingkungan kandang. Namun, berdasarkan hasil penelitian ini keberadaan bakteri patogen berdasarkan posisi puting tidak memiliki perbedaan yang nyata, yang ditunjukan oleh hasil uji khikuadrat dengan nilai $\mathrm{P}>0.05$ (Tabel 2). Hal tersebut dapat disebabkan karena identifikasi keberadaan bakteri patogen berdasarkan posisi puting dilakukan sebelum dan selama diberikan perlakuan celup puting, sehingga dapat menurunkan risiko masuknya bakteri melalui lubang puting.

Tidak terlihatnya perbedaan yang nyata terhadap keberadaan bakteri patogen berdasarkan posisi puting juga dapat disebabkan karena bakteri patogen tersebut dapat menular dari satu puting ke puting yang lain melalui tangan pemerah. Pemerah umumnya mencuci tangan setiap akan melakukan pemerahan pada sapi yang berbeda, namun pemerah biasanya tidak mencuci tangan kembali saat melakukan pemerahan dari satu puting ke puting lainnya pada seekor sapi. Hal tersebut dapat meningkatkan risiko penularan bakteri patogen penyebab mastitis subklinis pada puting yang terakhir diperah.

\section{Kesimpulan}

Kesimpulan dari penelitian ini adalah keberadaan bakteri patogen, Staphylococcus aureus, dan Escherichia coli mengalami penurunan yang nyata setelah diberi perlakuan celup puting, sedangkan, Streptococcus agalactiae tidak mengalami penurunan yang nyata. Keberadaan bakteri patogen tidak dipengaruhi oleh posisi puting.

\section{Ucapan Terima Kasih}

Terima kasih disampaikan kepada Dirjen Dikti yang telah mendanai penelitian ini melalui Penelitian Strategis Unggulan IPB dengan skim Penelitian Unggulan sesuai Mandat Divisi, Institut Pertanian Bogor, Dana DIPA IPB tahun anggaran 2015 nomor 571/IT3.11/PL/2015.

\section{Daftar Pustaka}

Brooks, G. F., Butel, J. S., Morse, S. A. (2008). Mikrobiologi Kedokteran. Ed ke-23. Nugroho, E., Maulany, penerjemah.. Terjemahan dari: Medical Microbiology. EGC. Jakarta. Indonesia: $544 \mathrm{hlm}$.

Connors, K. A. (1992). Stabilitas Kimiawi Sediaan Farmasi. Ed ke-2. Gunawan, D., penerjemah. Terjemahan dari: Chemical Stability Pharmaceuticals. IKIP Semarang Press. Semarang. Indonesia: hlm 268. 
[DITJENNAK KESWAN] Direktorat Jenderal Peternakan dan Kesehatan Hewan. (2013). Statistik Peternakan Tahun 2012. Direktorat Jenderal Peternakan dan Kesehatan Hewan. Jakarta. Indonesia.

[GKSI] Gabungan Koperasi Susu Indonesia. (2013). Profil Koperasi Primer. http://gksijawabarat. co.id/. Diakses pada tanggal 21 Februari 2016.

Mahardhika, O., Sudjatmogo, Suprayogi, T. H. (2012). Tampilan total bakteri dan $\mathrm{pH}$ pada susu kambing perah akibat dipping desinfektan yang berbeda [Total bacteria and $\mathrm{pH}$ of goat milk with various udder dipping methods]. Anim. Agric. J. 1(1):819-828.

Muttaqin, A. (2009). Asuhan Keperawatan Klien dengan Gangguan Sistem Kardiovaskular. Nurachmach E, editor. Salemba Medika. Jakarta. Indonesia: 20 .

Nurhayati, I., Martindah, E. 2015. Pengendalian mastitis subklinis melalui pemberian antibiotik saat periode kering pada sapi perah. Wartazoa. 25(2): 65-74.

Poeloengan, M. (2010). Aktivitas Air Perasan dan Ekstrak Etanol Daun Encok terhadap Bakteri yang Diisolasi dari Sapi Mastitis Subklinis [Activity water extract and ethanol extraction of Plumbago Zeylanica L. leaves against bacteria isolated from sub clinical mastitis in cattle]. Di dalam: Sani, Y., Natalia, L., Brahmantiyo, B., Pujiastuti, W., Sartika, T., Nurhayati, Anggraeni, A., Matondang, R.H., Martindah, E., Estuningsih, S.E., editor. Teknologi Peternakan dan Veteriner mendukung Industrialisasi Sistem Pertanian untuk Meningkatkan Ketahanan Pangan dan Kesejahteraan Peternak. Seminar Nasional Teknologi Peternakan dan Veteriner; 2009 Agu 13-14; Bogor, Indonesia. Pusat Penelitian dan Pengembangan Peternakan. Bogor: 300-305.

Putri, P., Sudjatmogo, Suprayogi, T. H. (2015). Pengaruh lama waktu dipping dengan menggunakan larutan kaporit terhadap tampilan total bakteri dan derajat keasaman susu sapi perah [The effect of durations time of dipping with kaporit on total bacteria and $\mathrm{pH}$ of dairy cows milk]. Anim. Agric. J. 4(1):132136.

Ryan, K. J. and Ray, C.G. (2004). Sherris Medical Microbiology. 4th ed. McGraw-Hill. Boston. USA: 273-296.

Siregar, A. Z. 2010. Pengaruh celup puting sari buah mengkudu (Morinda Citrifolia L) terhadap kasus mastitis subklinis pada sapi perah berdasarkan pemeriksaan total plate count. http://www.fkh.unair.ac.id/artikel1/2010/ ARTIKEL\%20ILMIAH\%20A.pdf.[3 Februari 2015].

Songer, J. G. and Post, K.W. (2005). Veterinary Microbiology Bacterial and Fungal Agents of Animal Disease. Elsevier Saunders. Philadelphia. USA: 448 p.

Subronto. (2003). Ilmu Penyakit Ternak I. Gajah Mada Univ. Press. Yogyakarta. Indonesia: 701 hlm.

Sudarwanto, M.B. (1998). Pereaksi IPB-1 sebagai pereaksi alternatif untuk mendeteksi matitis subklinis [The IPB-1 reagent as an alternative tool to detect subclinical mastitis]. Med. Vet. $5(1): 1-5$.

Supar, Ariyanti, T. (2008). Kajian pengendalian mastitis subklinis pada sapi perah [Studies on subclinical mastitis control in the dairy cows]. Di dalam: Diwyanto, K., Wina, E., Priyanti, A., Natalia, L., Herawati, T., Purwandaya, B., editor. Semiloka Nasional Prospek Industri Sapi Perah Menuju Perdagangan Bebas 2020; 2008 Apr 21; Jakarta, Indonesia. Pusat Penelitian dan Pengembangan Peternakan. Bogor. Indonesia: hlm 360-366.

White, D.G. (2006). Antimicrobial resistance in pathogenic Escherichia coli from animals. Di dalam: Aarestrup, F.M, editor. Antimicrobial Resistance in Bacteria of Animal Origin. Am. Soc. for Microbiol. Press. Washington DC. USA: hlm 145-166. 